This is the author's final, peer-reviewed manuscript as accepted for publication. The publisher-formatted version may be available through the publisher's web site or your institution's library.

\title{
Environmental policies for a multifunctional agricultural sector in open economies
}

Jeffrey M. Peterson, Richard N. Boisvert, Harry de Gorter

\section{How to cite this manuscript}

If you make reference to this version of the manuscript, use the following information:

Peterson, J. M., Boisvert, R. N., \& de Gorter, H. (2002). Environmental policies for a multifunctional agricultural sector in open economies. Retrieved from http://krex.ksu.edu

\section{Published Version Information}

Citation: Peterson, J. M., Boisvert, R. N., \& de Gorter, H. (2002). Environmental policies for a multifunctional agricultural sector in open economies. European Review of Agricultural Economics, 29(4), 423-443.

Copyright: (๑) Oxford University Press and Foundation for the European Review of Agricultural Economics 2002

Digital Object Identifier (DOI): doi:10.1093/eurrag/29.4.423

Publisher's Link: http://erae.oxfordjournals.org/content/29/4/423.abstract

This item was retrieved from the K-State Research Exchange (K-REx), the institutional repository of Kansas State University. K-REx is available at http://krex.ksu.edu 


\title{
Environmental Policies for a Multifunctional Agricultural Sector in Open Economies
}

\author{
Jeffrey M. Peterson \\ Assistant Professor \\ Department of Agricultural Economics \\ Kansas State University \\ Richard N. Boisvert \\ Professor \\ Department of Applied Economics and Management \\ Cornell University \\ Harry de Gorter \\ Associate Professor \\ Department of Applied Economics and Management \\ Cornell University
}

May 2002

Contact: Jeffrey M. Peterson

331B Waters Hall

Department of Agricultural Economics

Kansas State University

Manhattan, KS 66506-4011, U.S.A.

Email: jpeters@ksu.edu

Phone: +1-785-532-4487

Fax: +1-785-532-6925

The authors wish to thank Nancy Chau, Andrew Barkley, the editor, and three anonymous reviewers for helpful comments and suggestions. Any remaining errors are our own. The research on which this paper is based was supported in part by the Cornell Agricultural Experiment Station with funds from the Cooperative State Research, Education, and Extension Service, U. S. Department of Agriculture, Projects NYC-121444 and NYC-121490. Any opinions, findings, or conclusions are those of the authors and do not necessarily reflect the view of the U. S. Department of Agriculture. 


\title{
Environmental Policies for a Multifunctional Agricultural Sector in Open Economies
}

\begin{abstract}
This paper derives the efficient set of policies for a multifunctional agriculture and relates them to trade. In general, efficiency cannot be achieved through simple output subsidies, but the efficient policies to move closer to socially optimal levels of multifunctional, non-commodity outputs may also change commodity output levels. Accounting for international price effects, large importing and exporting nations have incentives to favour subsidies for non-commodity outputs and oppose them, respectively, regardless of the true value of these agriculturally-related public goods. The policy incentives are illustrated through a stylised simulation of United States’ agriculture.
\end{abstract}

Keywords: Multifunctionality, agricultural trade, environmental policy 


\section{Environmental Policies for a Multifunctional Agricultural Sector in Open Economies}

\section{Introduction}

Recent agricultural policy and trade discussions have given increasing attention to 'multifunctionality,' the notion that agriculture provides multiple outputs that include public goods as well as privately traded commodities (Runge, 1998; Organisation for Economic Cooperation and Development, 1997; Lindland, 1998). Examples of these public goods are landscape amenities, wildlife habitat, and agrarian heritage, although public "bads" such as pollution from farm chemicals have been documented as well. In the World Trade Organisation (WTO) negotiations, various countries have taken different positions along a continuum of views on multifunctionality, generating an impasse that will be difficult to resolve (Blandford and Boisvert, forthcoming; Blandford and Fulponi, 1999; Anderson and Hoekman, 1999).

At one extreme are high-cost agricultural producing countries with high levels of support (e.g., Japan and the European Union), who argue that farm subsidies are the efficient way to secure public goods that are by-products of farm output (e.g. World Trade Organisation, 1999; Norwegian Royal Ministry of Agriculture, 1998). WTO rules currently require steady reductions in support levels, changes which these nations claim will jeopardize the public-good functions of agriculture. They conclude that the support level rules should be renegotiated with environmental safeguards in mind.

The other extreme of low-cost producers (e.g., the Cairns Group and the United States) question whether the public good values are truly significant, and claim that so-called environmental safeguards are just trade-distorting protectionism in disguise. These countries argue that subsidies on output cannot efficiently provide public good by-products even if they are valuable, emphasizing that current WTO rules already allow environmental goals to be pursued 
through decoupled 'green box' policies that do not distort production levels (World Trade Organisation, 1998; Bohman et al., 1999).

In this paper, we develop a model of agricultural policy that illuminates the important interaction between the multifunctional technology and policy instruments. For a general specification of multifunctional technology, the efficient policy may include an output subsidy, but the subsidy must be accompanied by input taxes, subsidies, or regulations, and the efficient levels of all outputs can be achieved without an output subsidy at all. If there are non-allocable inputs, then the efficient policy may also change production and trade flows.

Our model also reveals the complexity in setting efficient policies, which generally include instruments on a set of farm inputs. The information requirements for such a policy would be very high. Even more complexity arises from the large country case, since the effect on world prices must be taken into account.

Finding the efficient set of policies under multifunctionality has so far received little attention by agricultural economists. An exception is Vatn (forthcoming), who recently examined the effect of transactions costs on the efficient policies to acquire public goods. We extend this line of inquiry by identifying the different welfare incentives in small and large countries and relating the policy set to jointness in production.

We also build on several results in the trade and environmental economics literature. The notions of joint production we use to characterize multifunctionality are based on the results of Leathers (1991) and Lau (1972). Assuming production is joint, we derive a policy scheme to simultaneously correct a positive and a negative externality through taxes/subsidies on inputs and outputs, which extends the optimal input taxes for a single externality derived by Holtermann (1976) and Stevens (1988). Finally, the large economy results build upon the large body of 
literature on the relationship between environmental policy and trade (e.g., Copeland, 1994; Krutilla, 1991; Beghin et al., 1997; Schamel and de Gorter, 1997), again generalizing the single externality results to the multiple externality case.

The remainder of the paper is organized as follows. The second section presents our model of multifunctional agricultural production. We specify a general form of technology and derive the efficient policies for both small and large trading nations. Section 3 illustrates the policy results through a stylised numerical simulation of U.S. agriculture. The final section summarises the results and discusses the implications for policy and trade negotiations.

\section{A Model of a Multifunctional Agricultural Sector}

\subsection{Agricultural Technology}

In its most general form, the technology for any agricultural commodity can be described by the transformation frontier:

$$
\mathrm{T}(\mathrm{y}, \mathrm{a}, \mathrm{e}, \mathrm{L}, \mathrm{Z})=0
$$

where $y$ is the output of the commodity in question, a is a set of positively valued amenities, e represents negatively valued emissions, $\mathrm{L}$ is the amount of land in production, and $\mathrm{Z}$ is a vector of non-land inputs. To capture the essence of multifunctionality, it is not essential to agree completely on the specific non-commodity outputs to be included in the definition, but it is critical to realize there are positively as well as negatively valued non-commodity outputs (Blandford and Boisvert, forthcoming). The distinguishing feature of these non-commodity outputs is that they have public good characteristics or are externalities, neither of which is traded in organised markets. While the model could be developed for an arbitrary number of externalities in each category, we assume for simplicity that a and e are one-dimensional. 
The policy significance of the non-commodity outputs can be understood through the concept of joint production. From an analytical point of view, Baumol et al. (1981) relied on the concept of jointness in production to explain the existence of multiproduct firms. More recent research has focused on the implications of jointness in modelling commodity output supply and factor demand systems in agriculture (e.g. Shumway et al., 1984)). In general, two outputs are said to be joint if their production is interlinked in some way. ${ }^{1}$ Regardless of the cause of these inter-linkages, Leathers (1991) demonstrated that jointness gives rise to cost complementarities among the outputs, so that producing them separately is more expensive than producing them together. Such complementarities are often referred to as “economies of scope.”

Perhaps the classic definition of joint products was offered by authors such as Marshall (1959) and Carlson (1956) when referring to things, such as oats and straw or wool and mutton, that cannot be produced separately but are joined by a common origin or non-allocable input. These examples are often thought to represent the special case of production in fixed proportions, but in reality even in these cases, the proportions can vary within narrow ranges in the long run by choosing different livestock breeds or crop varieties. At the other extreme, there are joint products for which the proportions can vary more widely and do so in response to relative price changes.

It is this latter situation that is likely to be the case for private and public outputs of agriculture. In the notation introduced above, the outputs $y$, a, and e can be produced in varying proportions by reallocating the inputs $\mathrm{L}$ and $\mathrm{Z}$. A farmer may increase the amenity output in proportion to the others, for example, by devoting some labour to constructing stone fences. The amount of pollution may be reduced in proportion to the other outputs by using alternative methods for applying chemicals. ${ }^{2}$ 
The existence of non-allocable inputs in agriculture also gives rise to joint production of private and public outputs, but again, not in fixed proportions, if for no other reason than the proportions can vary depending on the choice of production technique. Further, the same amount of commodity output could be produced using less land and more labour, but the supply of amenities relative to commodity output would be reduced. More importantly, the inputs that produce the public outputs cannot be distinguished from those producing the private outputs. For example, land in crops contributes both to commodity output and landscape amenities, but it is impossible to disentangle land's separate contributions to each output. The same is true for polluting inputs such as fertiliser, which simultaneously contributes to commodity output and pollution. This is the essence of joint production, and Lau (1972) showed that the presence of non-allocable inputs leads to a set of supply functions whereby the supply of each output depends on the prices of other outputs. Thus, the technical interdependence due to the nonallocable input also gives rise to this economic interdependence. ${ }^{3}$ The fact that farmers currently produce these commodity and non-commodity outputs jointly even though they receive an effective price of zero for the public outputs is strong evidence of joint technology.

The fact that farm output supply and input demand decisions do not reflect the value society places on these public good outputs makes policy comparisons difficult. To "level” the policy playing field for comparisons of commodity and non-commodity policy, one need only place explicit values on the non-commodity outputs so that farmers are rewarded for producing non-commodity outputs with positive values, but are penalised for producing those that impose social costs (Blandford and Boisvert, forthcoming). This is the well-known Pigouvian solution (Spulber, 1985), and its properties can be theoretically identified through an indirect profit function that depends on the prices of all outputs. Unfortunately, such an approach is not of 
much help in policy practice because it assumes that all multifunctional outputs can be observed easily, measured, and priced. We proceed by deriving the output relationships with the profit function, and then show how technology must be modelled to set actual policies.

The profit function for the general technology in equation (1) can be written explicitly by noting that $\mathrm{Z}$ contains allocable as well as non-allocable inputs, because some non-land inputs can be allocated across different activities. As mentioned above, an example of such an input would be farm labour, which can be allocated across amenity-enhancing activities and commodity production. This implies that the vector of non-land inputs can be partitioned such that $\mathrm{Z}=(\mathrm{X}, \mathrm{W})$, where $\mathrm{X}$ and $\mathrm{W}$ are non-allocable and allocable inputs, respectively. The technology in (1) can then be written using production functions for the three outputs:

$$
\begin{gathered}
\mathrm{T}\left(\mathrm{F}\left(\mathrm{L}, \mathrm{X}, \mathrm{W}_{\mathrm{y}}\right), \mathrm{A}\left(\mathrm{L}, \mathrm{X}, \mathrm{W}_{\mathrm{a}}\right), \mathrm{E}\left(\mathrm{L}, \mathrm{X}, \mathrm{W}_{\mathrm{e}}\right), \mathrm{L}, \mathrm{X}, \mathrm{W}\right)=0 \\
\text { where } \mathrm{W}_{\mathrm{y}}+\mathrm{W}_{\mathrm{a}}+\mathrm{W}_{\mathrm{e}}=\mathrm{W}
\end{gathered}
$$

$\mathrm{F}(\cdot), \mathrm{A}(\cdot)$, and $\mathrm{E}(\cdot)$ are the production functions for the commodity, amenity, and emission outputs, respectively, and $\mathrm{W}_{\mathrm{j}}$ is the vector of allocable inputs devoted to output $\mathrm{j}$. Using this specification of technology, the indirect profit function is:

$$
\begin{gathered}
\pi\left(p_{y}, p_{a}, p_{e}, p_{L}, p_{X}, p_{w}\right)=\underset{\left\{L, X, W_{y}, W_{a}, W_{e}\right\}}{\operatorname{Max}} p_{y} F\left(L, X, W_{y}\right)+p_{a} A\left(L, X, W_{a}\right)-p_{e} E\left(L, X, W_{e}\right) \\
-p_{L} L-p_{X} X-p_{W}\left(W_{y}+W_{a}+W_{e}\right)
\end{gathered}
$$

where $\mathrm{p}_{\mathrm{j}}$ is the price of output or input $\mathrm{j}$. Assuming an interior solution, the first-order necessary conditions for the maximisation in (2) imply that:

$$
\begin{gathered}
\mathrm{p}_{\mathrm{y}} \mathrm{F}_{\mathrm{L}}+\mathrm{p}_{\mathrm{a}} \mathrm{A}_{\mathrm{L}}-\mathrm{p}_{\mathrm{e}} \mathrm{E}_{\mathrm{L}}=\mathrm{p}_{\mathrm{L}} \\
\mathrm{p}_{\mathrm{y}} \mathrm{F}_{\mathrm{X}_{\mathrm{i}}}+\mathrm{p}_{\mathrm{a}} \mathrm{A}_{\mathrm{X}_{\mathrm{i}}}-\mathrm{p}_{\mathrm{e}} \mathrm{E}_{\mathrm{X}_{\mathrm{i}}}=\mathrm{p}_{\mathrm{X}_{\mathrm{i}}} \\
\mathrm{p}_{\mathrm{y}} \mathrm{F}_{\mathrm{W}_{\mathrm{i}}}=\mathrm{p}_{\mathrm{W}_{\mathrm{i}}} \\
\mathrm{p}_{\mathrm{a}} \mathrm{F}_{\mathrm{W}_{\mathrm{i}}}=\mathrm{p}_{\mathrm{W}_{\mathrm{i}}}
\end{gathered}
$$




$$
-\mathrm{p}_{\mathrm{e}} \mathrm{F}_{\mathrm{W}_{\mathrm{i}}}=\mathrm{p}_{\mathrm{W}_{\mathrm{i}}}
$$

where subscripts on $\mathrm{F}, \mathrm{A}$, and $\mathrm{E}$ represent partial derivatives, $\mathrm{X}_{\mathrm{i}}$ is the ith non-allocable input, and $\mathrm{W}_{\mathrm{i}}$ is the ith allocable input. Let $\left(\mathrm{L}^{*}, \mathrm{X}^{*}, \mathrm{~W}^{*}\right)$ denote the socially optimal solution, where $\mathrm{p}_{\mathrm{a}}$ and $\mathrm{p}_{\mathrm{e}}$ reflect the social values of the public outputs.

The conditions above reveal the fundamental difference between allocable and nonallocable inputs for policy purposes. The optimal level of each non-allocable input $\left(\mathrm{L}^{*}\right.$ or $\left.\mathrm{X}_{\mathrm{i}}^{*}\right)$ occurs where the price of that input equals the sum of the marginal value products for the private and public outputs (conditions (3) and (4)). If farmers face effective prices of $p_{a}=p_{e}=0$, the non-allocable inputs will be used at socially inefficient levels because the marginal values of the public outputs will not be included in the input decision. The optimal level of each allocable input consists of three separate quantities: $\mathrm{W}_{\mathrm{i}}{ }^{*}=\mathrm{W}_{\mathrm{iy}}{ }^{*}+\mathrm{W}_{\mathrm{ia}}{ }^{*}+\mathrm{W}_{\mathrm{ie}}{ }^{*}$, where $\mathrm{W}_{\mathrm{ij}}{ }^{*}$ is the value of allocable input $\mathrm{i}$ such that its price equals its marginal value product in producing output $\mathrm{j}$ (conditions (5) - (7)). Zero prices for the public outputs imply that allocable inputs would be devoted only to private goods, because the effective marginal value products of the public outputs are zero.

Conceptually, a government could achieve efficiency either by subsidising the public outputs at their social values, or by directly regulating the quantities of environmental outputs at their socially optimal levels. For agriculture, the difficulty is that a and e are almost always unobservable, or not measurable in a traditional way, so they can neither be priced nor regulated directly. The only practical policies are those that act on the observable outputs and inputs (y, L, and Z). However, it is not sufficient to act on the prices (or quantities) of those goods alone. If $\mathrm{p}_{\mathrm{a}}=\mathrm{p}_{\mathrm{e}}=0$, changes in $\mathrm{p}_{\mathrm{y}}, \mathrm{p}_{\mathrm{L}}$, or $\mathrm{p}_{\mathrm{z}}$ will not achieve the efficient outcome, since they will alter the total amount of private output and inputs but not the amount of allocable inputs devoted to 
each activity. This can be clearly seen from conditions (6) and (7), which imply that if $\mathrm{p}_{a}=\mathrm{p}_{\mathrm{e}}=$ 0 , then $\mathrm{W}_{\mathrm{ia}}$ and $\mathrm{W}_{\mathrm{ie}}$ will not equal their efficient levels no matter how $\mathrm{p}_{\mathrm{W}_{\mathrm{i}}}$ or $\mathrm{p}_{\mathrm{y}}$ are set. Similarly, if regulations require that an allocable input be used at its efficient quantity $\mathrm{W}_{\mathrm{i}}{ }^{*}$, a farmer would have no incentive to divide it in the efficient combination across activities.

Therefore, the only way to develop efficient policies is to regard the amount of an allocable input devoted to each activity as a distinct input. For example, to achieve the socially efficient allocation of labour, policies must distinguish between the labour devoted to commodity production and the labour devoted to amenity enhancement. Mathematically, this means that the vector $\mathrm{W}$ must be redefined so that $\mathrm{W}_{\mathrm{iy}}, \mathrm{W}_{\mathrm{ia}}$, and $\mathrm{W}_{\mathrm{ie}}$ are separate entries. This redefinition allows the inputs in $\mathrm{W}$ to be treated the same as the non-allocable inputs in the profit maximisation problem, since the derivatives with respect to $\mathrm{W}_{\mathrm{ij}}$ equal zero for all outputs except the jth by assumption. Now letting $\mathrm{Z}$ represent the correspondingly redefined vector of all inputs, we can write production functions of the form:

$$
\mathrm{y}=\mathrm{F}(\mathrm{L}, \mathrm{Z}), \quad \mathrm{a}=\mathrm{A}(\mathrm{L}, \mathrm{Z}), \quad \mathrm{e}=\mathrm{E}(\mathrm{L}, \mathrm{Z})
$$

These functions satisfy:

$$
\mathrm{T}(\mathrm{F}(\mathrm{L}, \mathrm{Z}), \mathrm{A}(\mathrm{L}, \mathrm{Z}), \mathrm{E}(\mathrm{L}, \mathrm{Z}), \mathrm{L}, \mathrm{Z})=0
$$

An input in $\mathrm{Z}$ may have different effects on the three outputs. Similar to the definitions in Stevens (1988), if $Z_{i}$ is an amenity-enhancing input, then $A_{Z_{i}}>0$; polluting inputs and pollutionabating inputs satisfy $E_{Z_{i}}>0$ and $E_{Z_{i}}<0$, respectively. The marginal effect of an input on commodity output, $\mathrm{F}_{\mathrm{Z}_{\mathrm{i}}}$, may be positive, zero, or negative. While each (redefined) allocable input yields a non-zero derivative for only one output, the non-allocable inputs must generate non-zero derivatives for at least two of the outputs. 


\subsection{The Social Optimum}

Having specified agricultural technology in an appropriate way, we can now derive the set of optimal policies. We achieve this using a partial equilibrium model, where consumers place a value on all three agricultural outputs, but only food is purchased through an organised market. Parallel results were derived in a general equilibrium setting by Peterson (2000). To find the optimal policies, we first derive the conditions for a socially optimal allocation of factors, and then find the equilibrium conditions for policy instruments at arbitrary levels. The optimal policies are then set to make the equilibrium and optimal conditions coincide.

Social welfare can be represented by the sum of consumer and producer surplus, or:

$$
W=\int_{p_{y}}^{\infty} x\left(\tilde{p}_{y}\right) d \tilde{p}_{y}+B(a)-D(e)+p_{y} y-p_{L} L-p_{z} Z
$$

where $\mathrm{x}\left(\mathrm{p}_{\mathrm{y}}\right)$ is the domestic demand function, $\mathrm{B}(\mathrm{a})$ represents the social benefits of agricultural amenities, $\mathrm{D}(\mathrm{e})$ represents the social damages from pollution, and $\mathrm{p}_{\mathrm{L}}$ and $\mathrm{p}_{\mathrm{z}}$ are exogenous factor prices that represent the full social value of the factors in the next best alternative. ${ }^{4}$ The first three terms in (10) represent consumer surplus (the area between the demand curve and price, plus adjustments for the value of externalities) while the last three terms are producer surplus, equal to farm profits. Abstracting from any fixed tariff or transportation wedge between domestic and world prices, the equilibrium price $\mathrm{p}_{\mathrm{y}}$ in an open economy is determined by the equation: ${ }^{5}$

$$
y=x\left(p_{y}\right)+x^{*}\left(p_{y}\right)
$$

where $x^{*}\left(p_{y}\right)$ is the net foreign demand function, which is positive, negative, and zero, respectively for exporting, importing, and closed-border nations. Assume that $\mathrm{x}^{\prime}\left(\mathrm{p}_{\mathrm{y}}\right)<0$ and $\mathrm{x}^{* \prime}\left(\mathrm{p}_{\mathrm{y}}\right)<0 .:$ 
Given the technology specified above, the social planner's problem is one of maximising welfare in (10), subject to the constraints (8) and (11). Substituting $y=F(L, Z$ ) into (11) implicitly defines a price function $\mathrm{p}_{\mathrm{y}}(\mathrm{L}, \mathrm{Z})$ that maps the factor committal to the equilibrium world price. For a small country, $\partial \mathrm{p}_{\mathrm{y}} / \partial \mathrm{p}_{\mathrm{L}}=\partial \mathrm{p}_{\mathrm{y}} / \partial \mathrm{p}_{\mathrm{z}_{\mathrm{i}}}=0$, because domestic production does not influence the world price. It can be easily proven for a large country that $\partial \mathrm{p}_{\mathrm{y}} / \partial \mathrm{p}_{\mathrm{L}}<0$ and $\partial \mathrm{p}_{\mathrm{y}} / \partial \mathrm{p}_{\mathrm{z}_{\mathrm{i}}}<0$; a ceteris paribus increase in either of the factors of production generates more output and a lower market clearing price. ${ }^{6}$

Substituting the price function and the remaining constraints into (10), the problem becomes:

$$
\operatorname{Max} \int_{p_{y}(L, Z)}^{\infty} x\left(\tilde{p}_{y}\right) d \tilde{p}_{y}+B(A(L, Z))-D(E(L, Z))+p_{y}(L, Z) F(L, Z)-p_{L} L-p_{z} Z
$$

where the decision variables are $\mathrm{L}$ and $\mathrm{Z}$. $\mathrm{L}$ is one-dimensional because land is non-allocable; let $\mathrm{n}$ represent the number of non-land inputs in Z. The first-order necessary conditions are:

$$
\begin{gathered}
-x\left(p_{y}\right) \frac{\partial p_{y}}{\partial L}+B^{\prime}(\cdot) A_{L}-D^{\prime}(\cdot) E_{L}+\frac{\partial p_{y}}{\partial L} F(L, Z)+p_{y} F_{L}-p_{L}=0 \\
-x\left(p_{y}\right) \frac{\partial p_{y}}{\partial Z_{i}}+B^{\prime}(\cdot) A_{Z i}-D^{\prime}(\cdot) E_{Z i}+\frac{\partial p_{y}}{\partial Z_{i}} F(L, Z)+p_{y} F_{Z i}-p_{Z i}=0, \quad i=1, \ldots, n
\end{gathered}
$$

Substituting the relationship $x^{*}\left(p_{y}\right)=F(L, Z)-x\left(p_{y}\right)$ and rearranging, these conditions reduce to:

$$
\begin{gathered}
\mathrm{p}_{\mathrm{y}} \mathrm{F}_{\mathrm{L}}+\mathrm{B}^{\prime}(\cdot) \mathrm{A}_{\mathrm{L}}-\mathrm{D}^{\prime}(\cdot) \mathrm{E}_{\mathrm{L}}+\mathrm{x}^{*}\left(\mathrm{p}_{\mathrm{y}}\right) \frac{\partial \mathrm{p}_{\mathrm{y}}}{\partial \mathrm{L}}=\mathrm{p}_{\mathrm{L}} \\
\mathrm{p}_{\mathrm{y}} \mathrm{F}_{\mathrm{Zi}}+\mathrm{B}^{\prime}(\cdot) \mathrm{A}_{\mathrm{Zi}}-\mathrm{D}^{\prime}(\cdot) \mathrm{E}_{\mathrm{Zi}}+\mathrm{X}^{*}\left(\mathrm{p}_{\mathrm{y}}\right) \frac{\partial \mathrm{p}_{\mathrm{y}}}{\partial \mathrm{Z}_{\mathrm{i}}}=\mathrm{p}_{\mathrm{Zi}}, \quad \mathrm{i}=1, \ldots, \mathrm{n}
\end{gathered}
$$

Each of these conditions requires the marginal social benefits of an input to equal its marginal social costs. The first three terms in each equation represent the marginal benefits from 
producing each of the outputs, while the fourth term represents the change in the value of exports from an increase in prices. The latter is a terms-of-trade distortion analogous to an optimal tariff, which will be discussed further below. Note that this term is zero for a small economy since the world price is constant. Denote the solution to the planner's problem by $\left(\mathrm{L}^{0}, \mathrm{Z}^{0}\right)$.

\subsection{Optimal Policies, Small Economy}

Consider the competitive equilibrium in a small economy with a set of taxes and subsidies on $y, L$, and $Z$. This equilibrium will be made up of an exogenous world price $p_{y}$, exogenous factor prices $\mathrm{p}_{\mathrm{L}}$ and $\mathrm{p}_{\mathrm{z}}$, and factor allocations $\mathrm{L}$ and $\mathrm{Z}$ that solve:

$$
\operatorname{Max}\left(p_{y}+s_{y}\right) F(L, Z)-\left(p_{L}-s_{L}\right) L-\left(p_{z}+t_{z}\right) Z
$$

where $\mathrm{s}_{\mathrm{y}}$ and $\mathrm{s}_{\mathrm{L}}$ are output and land subsidies and $\mathrm{t}_{\mathrm{z}}$ is a vector of taxes on non-land inputs. The first-order conditions to this problem satisfy:

$$
\begin{gathered}
\left(p_{y}+s_{y}\right) F_{L}=p_{L}-s_{L} \\
\left(p_{y}+s_{y}\right) F_{z_{i}}=p_{z_{i}}+t_{z_{i}}, \quad i=1, \ldots, n
\end{gathered}
$$

An optimal policy is a choice of ( $\left.\mathrm{s}_{\mathrm{y}}, \mathrm{s}_{\mathrm{L}}, \mathrm{t}_{\mathrm{Z}}\right)$ such that (15) and (16) coincide with (13) and (14) (where the derivatives of $\mathrm{p}_{\mathrm{y}}$ with respect to $\mathrm{L}$ and $\mathrm{Z}_{\mathrm{i}}$ all equal zero). Since there are a total of $\mathrm{n}+$ 2 instruments and $n+1$ conditions to be met, the government has a degree of freedom in selecting policies. For example, the output subsidy sy can be set arbitrarily and the remaining instruments must satisfy:

$$
\begin{gathered}
\mathrm{s}_{\mathrm{L}}=-\mathrm{s}_{\mathrm{y}} \mathrm{F}_{\mathrm{L}}+\mathrm{B}^{\prime}(\cdot) \mathrm{A}_{\mathrm{L}}-\mathrm{D}^{\prime}(\cdot) \mathrm{E}_{\mathrm{L}} \\
\mathrm{t}_{\mathrm{Z}_{\mathrm{i}}}=\mathrm{s}_{\mathrm{y}} \mathrm{F}_{\mathrm{Z}_{\mathrm{i}}}-\mathrm{B}^{\prime}(\cdot) \mathrm{A}_{\mathrm{Z}_{\mathrm{i}}}+\mathrm{D}^{\prime}(\cdot) \mathrm{E}_{\mathrm{Z}_{\mathrm{i}}}, \quad \mathrm{i}=1, \ldots, \mathrm{n}
\end{gathered}
$$

Though the arguments of the functions have been suppressed, optimality implies the expressions on the right-hand sides of both equations are evaluated at $\left(\mathrm{L}^{0}, \mathrm{Z}^{0}\right)$. While a commodity policy may be part of the optimal policy scheme, it is not necessary — a set of input taxes and subsidies 
can internalise all the non-market outputs even if $s_{y}=0$. Note also that any positive level of $s_{y}$ must be effectively offset by adjusting the input policies. If $\mathrm{s}_{\mathrm{y}}=0$, then the input policies are a straightforward generalization of previous results for a single externality (Stevens, 1988; Holtermann, 1976): each input is rewarded by the net marginal value of its contribution to the two externalities.

This implies, for example, that $t_{z_{i}}$ will be negative (a subsidy) for amenity-providing inputs that do not pollute, and it will be positive for polluting inputs that do not affect the amenity. Since land affects both public outputs, the sign of $s_{\mathrm{L}}$ is ambiguous. Indeed, the signs of $\mathrm{A}_{\mathrm{L}}$ and $\mathrm{E}_{\mathrm{L}}$ are themselves ambiguous, since they represent the marginal change in the public outputs assuming that non-land inputs are fixed. Intuitively, there are two effects of changing L when $\mathrm{Z}$ is fixed: the direct effect of bringing another acre into production, and the indirect effect of reducing the input use per acre Z/L. Note also that if the public outputs are truly joint products of food, then the policies must have an effect on the factor committal. On balance, there may be an effect on production. Thus, the effects of these joint policies may be somewhat at odds with the usual interpretation of the policies qualifying for the 'green box' in the WTOthat such measures would have a negligible impact on production levels.

To illustrate the relationship between the policies and the contribution of land, consider the following simple example. Suppose that land is of undifferentiated quality and that $\mathrm{Z}$ is onedimensional. Then total pollution can be written $\mathrm{e}=\operatorname{Lg}(\mathrm{z})$, where $\mathrm{g}(\cdot)$ is the per-acre pollution function and $z=Z / L$ is input use per acre. The function $g(z)$ satisfies $g^{\prime}(z)>0, g^{\prime \prime}(z)>0$ and $g(0)=0$. The marginal change in pollution with respect to $\mathrm{L}$ can then be computed as $\partial \mathrm{e} / \partial \mathrm{L}=$ $\mathrm{g}(\mathrm{z})+\mathrm{Lg}^{\prime}(\mathrm{z})\left(-\mathrm{Z} / \mathrm{L}^{2}\right)=\mathrm{g}(\mathrm{z})-\mathrm{g}^{\prime}(\mathrm{z}) \mathrm{z}<0 .{ }^{7}$ Assume that each acre of land provides a fixed amount of amenities, so that $\mathrm{a}=\alpha \mathrm{L}$. Then the optimal tax/subsidy scheme (with no output subsidy) is: 


$$
\begin{gathered}
\mathrm{s}_{\mathrm{L}}=\mathrm{B}^{\prime}(\cdot) \alpha-\mathrm{D}^{\prime}(\cdot)\left[\mathrm{g}(\mathrm{z})-\mathrm{g}^{\prime}(\mathrm{z}) \mathrm{z}\right] \\
\mathrm{t}_{\mathrm{Z}}=\mathrm{D}^{\prime}(\cdot) \mathrm{g}^{\prime}(\mathrm{z})
\end{gathered}
$$

Since the bracketed expression in (19) is negative, the optimal subsidy exceeds the amenity value of farmland. This extra payment to farmers is required to ensure efficiency at the extensive margin, and is equivalent to Spulber's (1985) lump-sum payment to ensure optimal entry and exit with an environmental product tax. The policy implication of this result is that even if agricultural land provides no landscape amenities (i.e., $\mathrm{B}(\mathrm{a}) \equiv 0$ ), it should still be subsidised in conjunction with the input tax $t_{z}$. Further, even with reliable estimates of $\mathrm{B}(\cdot), \alpha, \mathrm{D}(\cdot)$, and $\mathrm{g}(\cdot)$, subsidising land by the "net" value of amenities per acre will not achieve an efficient allocation of resources. Landscape amenity value net of pollution cost is $\left[\mathrm{B}^{\prime}(\cdot) \alpha-\mathrm{D}^{\prime}(\cdot) \mathrm{g}(\mathrm{z})\right]$, but this falls short of the optimal subsidy in (19) by the amount $g^{\prime}(\mathrm{z}) \mathrm{z}$. Thus, an empirical study of the willingness-to-pay for farmland amenities will not reveal the appropriate land subsidy, even if it accounts for the cost of agricultural pollution. ${ }^{8}$ We explore this issue further in the numerical illustration below.

\subsection{Optimal Policies, Large Economy}

For a large nation that seeks to maximise domestic welfare, the effect of agricultural inputs on the world price must be taken into account. Like the small economy, a competitive equilibrium is made up of the first-order conditions for profit maximisation (equations (15) and (16)), but the price $\mathrm{py}_{\mathrm{y}}$ is endogenous and must satisfy the market clearing relationship in equation (11). Since the price relationship is implicitly satisfied in the welfare-maximising conditions (13) and (14), the optimal tax/subsidy scheme becomes:

$$
s_{L}=-s_{y} F_{L}+B^{\prime}(\cdot) A_{L}-D^{\prime}(\cdot) E_{L}+x^{*}\left(p_{y}\right) \frac{\partial p_{y}}{\partial L}
$$




$$
\mathrm{t}_{\mathrm{z}_{\mathrm{i}}}=\mathrm{s}_{\mathrm{y}} \mathrm{F}_{\mathrm{Z}_{\mathrm{i}}}-\mathrm{B}^{\prime}(\cdot) \mathrm{A}_{\mathrm{z}_{\mathrm{i}}}+\mathrm{D}^{\prime}(\cdot) \mathrm{E}_{\mathrm{z}_{\mathrm{i}}}-\mathrm{x}^{*}\left(\mathrm{p}_{\mathrm{y}}\right) \frac{\partial \mathrm{p}_{\mathrm{y}}}{\partial \mathrm{Z}_{\mathrm{i}}}, \quad \mathrm{i}=1, \ldots, \mathrm{n}
$$

Compared to the small economy policies (equations (17) and (18)), each of these conditions contains an extra term equal to net exports times a derivative of the price function. Since the price derivative is negative, this term is positive for an importer and negative for an exporter. Stated differently, even without externalities, large importers prefer higher subsidies and lower taxes than large exporters. Alternatively, if externalities do exist, large importers have a welfare incentive to claim policy support is necessary to attain them, while large exporters do not. The intuition is the same as the single-externality case (Krutilla, 1991); importers gain from policies that increase production and decrease the world price, and conversely for exporters.

While the policies in (21) and (22) maximise domestic welfare, they are not globally optimal. The objective function to maximise global welfare takes the form:

$$
\operatorname{Max} \int_{p_{y}(L, Z)}^{\infty} x\left(\tilde{p}_{y}\right) d \tilde{p}_{y}+B(A(L, Z))-D(E(L, Z))+p_{y}(L, Z) F(L, Z)-p_{L} L-p_{z} Z+\int_{p_{y}(L, Z)}^{\infty} x *\left(\tilde{p}_{y}\right) d \tilde{p}_{y}
$$

This problem is the same as its domestic counterpart in equation (12), except for the last term that accounts for foreign welfare. Globally optimal policies can then be found following the same procedure as above: taking first-order conditions to (23) and comparing them with the competitive profit maximising conditions in (15) and (16). It can be easily verified that the resulting policies are identical to the domestic optimal policies for a small economy in equations (17) and (18). Thus, global efficiency requires either all trading nations are "small” or large countries are willing to ignore the terms-of-trade effects in setting environmental policy.

\section{A Numerical Illustration Based on U.S. Agriculture}

To illustrate the relationships between policies and their quantitative significance, we simulate the model for agricultural environmental policies in the United States. The U.S. is a net 
agricultural exporter, and a "large" country for many major commodities. Numerous forms of agricultural pollution have been documented, and we calibrate our model by focusing on a specific but widespread problem, the harmful effect of agricultural chemicals on human health. Based on empirical studies that have found significant non-market benefits for farmland (Halstead, 1984; Beasley et al., 1986; Bergstrom et al., 1985), we include the amenity value of the agricultural landscape.

Trade and environmental policies are simulated from the following model of the U.S. agricultural sector:

$$
\begin{gathered}
\mathrm{x}=\mathrm{k}_{\mathrm{x}} \mathrm{p}_{\mathrm{y}}^{-\eta_{\mathrm{x}}} ; \mathrm{x}^{*}=\mathrm{k}_{\mathrm{x}}^{*} \mathrm{p}^{-\eta_{\mathrm{x}}^{*}} \\
\mathrm{x}+\mathrm{x}^{*}=\mathrm{F}(\mathrm{L}, \mathrm{Z})=\mathrm{k}_{\mathrm{y}} \mathrm{L}^{\beta_{\mathrm{L}}} \mathrm{Z}^{\beta_{\mathrm{z}}} \\
\mathrm{p}_{\mathrm{y}} \mathrm{F}_{\mathrm{L}}=\mathrm{p}_{\mathrm{L}}-\mathrm{s}_{\mathrm{L}} ; \quad \mathrm{p}_{\mathrm{y}} \mathrm{F}_{\mathrm{Z}}=\mathrm{p}_{\mathrm{z}}+\mathrm{t}_{\mathrm{z}} \\
\mathrm{L}=\mathrm{k}_{\mathrm{L}} \mathrm{P}_{\mathrm{L}}^{\eta_{\mathrm{L}}} ; \mathrm{Z}=\mathrm{k}_{\mathrm{z}} \mathrm{P}_{\mathrm{Z}}^{\eta_{\mathrm{Z}}} \\
\mathrm{B}=\gamma \mathrm{L} ; \quad \mathrm{D}=\delta \mathrm{E}(\mathrm{L}, \mathrm{Z})=\delta \mathrm{k}_{\mathrm{E}} \mathrm{L}^{-1} \mathrm{Z}^{2}
\end{gathered}
$$

In this model, $\mathrm{x}$ and $\mathrm{x}^{*}$ represent the domestic and foreign demands, respectively, for a composite commodity representing U.S. farm output, and L and Z are indexes that represent the use of land and non-land inputs. Equations (24) specify the domestic and foreign demands to be of the constant elasticity form, where $\eta_{\mathrm{x}}$ and $\eta_{\mathrm{x}}{ }^{*}$ are the domestic and foreign demand elasticities. Equation (25) is the market clearing condition for agricultural goods, where agricultural output is produced according to a Cobb-Douglas production function. $\beta_{\mathrm{L}}$ and $\beta_{\mathrm{Z}}$ can be interpreted as production elasticities with respect to land and non-land inputs; assume that production is constant returns to scale (CRS) so that $\beta_{\mathrm{L}}+\beta_{\mathrm{Z}}=1$. Equations (26) are the profit maximisation conditions with a subsidy on land and a tax on non-land inputs. Equations (27) are 
the market clearing conditions for farm inputs, where the input supply functions are of constant elasticity form, and $\eta_{L}$ and $\eta_{Z}$ are the supply elasticities of the land and non-land inputs. Equations in (28) specify the value of the agricultural externalities, where $\gamma$ is the social amenity value per acre of farmland and $\delta$ is the social cost per unit of pollution. The pollution function is specified as the CRS form $E(L, Z)=k_{E} L^{-1} Z^{2}=L k_{E}(Z / L)^{2}$. While there is little scientific basis for any functional form of pollution, this quadratic function is used because it has a linear derivative in $\mathrm{Z}$, providing a first-order approximation to the underlying marginal health cost function.

This model is based on a framework widely used to simulate the aggregate effects of agricultural policies (Floyd, 1965; Gardner, 1987). It describes the agricultural sector in isolation, but preserves the relevant general equilibrium effects of non-fixed factor prices through the supply functions for $\mathrm{L}$ and $\mathrm{Z}$. Plausible ranges for the elasticity parameters were identified based on previous empirical studies, and multiple versions of the model were run to capture the sensitivity of the results to each parameter. For each version of the model, the functional constants (the $\mathrm{k}_{\mathrm{j}}$ 's) were calibrated to the given elasticities and observed data from U.S. agriculture for the year 1994.

Table 1 contains the base values and ranges chosen for all parameters. Based on substantial empirical evidence that supports a highly inelastic demand for food, $\eta_{\mathrm{x}}$ is varied throughout the range $[0.2,0.5]$. A range of $[2,10]$ is chosen for the export demand elasticity $\eta_{\mathrm{x}}{ }^{*}$ to reflect varying degrees of international market power. The ranges for the input supply elasticities $\eta_{L}$ and $\eta_{Z}$ are $[0.1,0.3]$ and $[5,15]$, respectively; land is inelastically supplied to agriculture because it total availability is fixed, but the supply of purchased inputs is elastic because they can be produced at very nearly constant cost.

[Table 1] 
Under CRS and profit maximisation, $\beta_{\mathrm{L}}$ and $\beta_{\mathrm{Z}}$ are the cost shares of land and non-land inputs, respectively. Based on aggregate agricultural production data available from the USDAEconomic Research Service (Ahearn et al., 1998; Ball et al., 1997), the average cost shares over the period 1948-1992 imply values of $\beta_{\mathrm{L}}=0.71$ and $\beta_{\mathrm{Z}}=0.29$; these parameters were varied in model over the ranges $[0.5,0.9]$ and $[0.1,0.5]$ respectively. The 'land input' $L$ in this data set is an aggregate that includes land itself and other inputs combined in proportion with it, while the 'non-land input' Z is made up of chemicals and other purchased inputs. These input aggregates were created in such a way that a subsidy on land alone is equivalent to the same subsidy on the entire land aggregate, and a tax on chemicals is equivalent to a tax on the non-land aggregate. ${ }^{9}$

Poe (1999) summarized several non-market valuation studies that have attempted to estimate the external benefits of farmland. Halstead (1984) and Bergstrom et al. (1985) have converted estimates of household willingness to pay to amenity values per acre by aggregating over households to obtain social willingness to pay, and dividing by the number of acres in the study region. Applying the estimates from these studies to a similar conversion procedure for aggregate data, estimated amenity values of farmland range from nearly zero to about $\$ 10$ per acre; the parameter $\gamma$ is thus varied throughout this range.

Because there is no standardized measure of agricultural pollution, $\delta$ is normalized to unity and e is measured in dollars of health costs from agricultural chemicals. The two primary categories of chemicals that pose health risks to humans are pesticides and nitrates in drinking water from the use of nitrogen fertilizer. Based on estimates of these damages from the environmental literature (Poe, 1998; Environmental Working Group, 1996; Schultz and Lindsay, 1990; Powell, 1990; Pimentel et al., 1992) the base value of e is varied from $\$ 2$ to $\$ 5$ billion. 
To explore the relationships among domestic environmental policies, the model is initially solved using the base values of the parameters for three policy scenarios that preclude trade distortion (Table 2). The land subsidy and chemical tax are computed based on equations (21) and (22), ignoring the last term in each expression that accommodates the world price effect. In scenario 1 , farmers receive no land subsidy but are charged a tax equal to the external cost of chemicals (nutrients and active ingredients in pesticides), or $\$ 0.14$ per pound applied. In scenario 2, chemicals are not taxed but land is subsidised at its marginal external value of $\$ 5.00$ per acre. Scenario 3 is the joint optimal policy, which is also globally efficient because both externalities are internalised without trade distortion. The latter case results in a chemical tax of \$0.14 per pound along with a land subsidy of \$7.67 per acre.

\section{[Table 2]}

The joint policy scenario illustrates the complexity involved in formulating efficient domestic programs. The optimal subsidy on an acre of farmland includes the $\$ 5$ it contributes to amenity value as well as its marginal effect on pollution; an extra acre of agricultural land reduces external health costs by $\$ 2.67$, ceteris paribus. ${ }^{10}$ Thus, the optimal subsidy differs from the amenity value of farmland by more than $50 \%$. Since non-land inputs are assumed to have no direct effect on amenities, the taxes in scenarios 1 and 3 are nearly identical. In this example, individual policies change both externalities in a desirable direction; an independent land subsidy increases landscape amenity value by $0.7 \%$ and also reduces health costs by $19 \%$, for example, but the changes are not as large as under the joint policy. In a parallel set of simulations, Peterson et al. (1999) found that the independent policies work at cross-purposes under the small country assumption. Independent policies may be welfare-reducing, and the correct joint policies cannot be computed in a straightforward way even if non-market values are known. 
As shown in the theoretical section above, the optimal allocation could not be achieved with an output subsidy alone. If an output subsidy were included, it would have to be offset by adjustments in the input policies. On the other hand, the efficient outcome does change production levels of all outputs, including the commodity, because the outputs are jointly produced. If there are both positive and negative externalities, then the efficient level of output could conceptually be larger or smaller than the competitive one. In sum, neither an output subsidy nor a decoupled policy is efficient.

Prices also respond from the changes in production, and the policies have varying impacts on domestic and foreign welfare. The joint tax and subsidy policy creates the largest net gain in combined welfare, although all three scenarios result in a net welfare improvement. Since the U.S. is a large country, none of these policies maximises welfare for the U.S. alone; the land subsidy in fact results in a small welfare loss. The domestic welfare maximising policies are reported in the last column of table 2 and include the effect of trade distortion (equations (21) and (22)). Since the U.S. is an exporter, it has an incentive to select policies that restrict production and, in turn, raise the international price. Therefore, the chemical tax of $\$ 0.29$ is more than twice as high as the no-distortion case, while the subsidy becomes negative ( $-\$ 7.38)$ so that land is effectively taxed as well. These policies do result in some environmental improvements because external health costs are reduced by over $30 \%$, but these gains are partially offset by a $0.7 \%$ decrease in the stock of farmland. The "environmental" policies provide additional welfare benefits through trade distortion, raising international prices by $9 \%$. Domestic welfare increases by $\$ 1.36$ billion and foreign welfare falls by nearly the same amount.

The sensitivity of the model results to changes in parameter values is summarised in Table 3. Three key variables - the land subsidy, the chemical tax, and the equilibrium price of 
food-are shown for both the non-distorting case (scenario 3) and the optimal domestic policy. The domestic and foreign demand elasticities $\left(\eta_{\mathrm{x}}\right.$ and $\left.\eta_{\mathrm{x}}{ }^{*}\right)$ have a very small effect on the results under no trade distortion. Consistent with expectations, the optimal domestic policy differs substantially depending on the degree of market power in international markets. The most extreme policies and price change occur with an export demand elasticity of -2 , when the optimal land subsidy is about $-\$ 19$ per acre and the price of food rises by $17 \%$. None of the model results is sensitive to changes in the supply elasticities of farm inputs $\left(\eta_{L}\right.$ and $\left.\eta_{Z}\right)$, suggesting that the general equilibrium effects of variable factor prices are not important in understanding optimal policies.

[Table 3]

Both the subsidy and the tax are negatively related to the production elasticity of land $\beta_{\mathrm{L}}$. This can be understood through the effect on the input intensity $z=Z / L$. In the no-distortion case the tax and subsidy are given by $\mathrm{t}_{\mathrm{z}}=2 \mathrm{k}_{\mathrm{E}} \mathrm{Z}$ and $\mathrm{s}_{\mathrm{L}}=\gamma+\mathrm{k}_{\mathrm{E}} \mathrm{Z}^{2}$, where the second term in $\mathrm{s}_{\mathrm{L}}$ is the marginal effect of land on emissions. Under CRS, an increase in $\beta_{\mathrm{L}}$ implies a decrease in $\beta_{\mathrm{Z}}$; these changes lead to a decrease in $\mathrm{z}$, and in turn reductions in $\mathrm{t}_{\mathrm{z}}$ and $\mathrm{s}_{\mathrm{L}}$. In the optimal domestic case, the effects are even more pronounced because the decrease in $\mathrm{z}$ lowers production and raises the international commodity price. Naturally, the subsidy and tax respond directly to changes in the amenity value $\gamma$ and aggregate health costs e.

\section{Policy Implications}

The notion of multifunctionality has sometimes been invoked to argue that protecting domestic agriculture may be justified on welfare grounds because some of the important multifunctional outputs are public goods. Economists have acknowledged this argument as being conceptually valid, but have pointed out that attempts to use trade policy violates the 
'specificity principle' for correcting distortions: an optimal policy must target the problem at its source rather than at the border (Bhagwati, 1969). From this perspective, the question of whether to use an output subsidy to obtain public goods is simple: such a policy is efficient only in the extremely unlikely event that all multifunctional public goods have positive social values, and, in addition, production of the non-commodity outputs is in fixed proportions with the production of commodity outputs.

Some countries also insist that public goods can be secured through decoupled policies that, at least in theory, do not change in commodity production, but again, this argument holds only if every input could be allocated separately in the production of either public goods or private ones. Given that land is almost always non-allocable, an optimal policy for many noncommodity outputs is likely to have an effect on food production. Conceptually, if there are both positively and negatively valued public goods, then the change in agricultural output could go in either direction; in our simulation of U.S. agriculture, agricultural output decreased with an optimal policy because the effect of chemical tax was larger than that of land subsidy.

Under these conditions, the question becomes: Can the WTO negotiations lead to an agreement that gives nations the autonomy to develop efficient policies? This remains a complex issue because in practice, government policy makers react not only to broad policy goals but also to the political support of domestic constituent groups. ${ }^{11}$ As such, the welfare objectives identified in our model offer only a partial explanation of actual policy choices. Nonetheless several of the model's predictions coincide with policy experience. The model predicts that all small countries with non-market outputs from agriculture support a positive land subsidy. This holds regardless of whether farmland provides any amenity benefits, because the land payment is needed to correct for the costs of the distortions created by pollution-control 
policies. Since amenities are non-rival in consumption, we would expect that amenity benefits are larger for land-scarce countries with a large population, causing such nations to support higher subsidies. Large importers (exporters) have an additional welfare incentive to support higher (lower) subsidies. Taken together, these results imply that subsidies are most likely to be supported by economically large, densely populated importing nations, and are most likely to be opposed by sparsely populated exporters.

A major obstacle in finding agreement during WTO negotiations is that negotiators may have an incentive to misrepresent the true situation. A densely populated, high-income nation such as Japan may legitimately place high values on the public goods from agriculture, but such a nation may also have an incentive to misrepresent the values of these public goods if it is a large importer of food. Sceptical trading partners such as the United States often point to this fact; in response, Japan can claim that as a large exporter, the United States has a similar incentive to claim the values of these public goods are low. Thus, neither side can distance itself from the accusation that it has abused the idea of multifunctionality in its favour. ${ }^{12}$

If economic efficiency and the maximisation of social welfare are the objectives, these conclusions suggest that any resolution to the multifunctionality issue within the current agricultural policy framework would be problematic. To achieve efficiency, the agreed upon rule cannot allow large nations to tie public-good policies to price supports for agriculture, since they have an incentive to abuse such a policy to distort world prices. Since the public outputs themselves are generally unobservable, the optimal policy scheme is necessarily a complex set of input taxes, subsidies, or regulations that must be chosen jointly in a way that takes their interaction into account. The need for detailed information is substantial, and this issue is further compounded by the problem of spatial diversity. Such complexity was evident even in a very 
simple illustrative simulation of U.S. agriculture, where the optimal policy included a land subsidy that differed from its non-market value by about $50 \%$.

Assuming that the information can be reliably collected, the administrative cost of implementing and enforcing such detailed joint policies would still be high. When taken together, these various transactions costs of efficient policies could be large. Differences in transactions costs across the input and output policies may resolve the over-identification problem (more instruments than conditions). In principle, a welfare-maximising government may choose a policy mix that appears inefficient unless the size of these transactions costs are recognised explicitly (Vatn, forthcoming).

Because of the spatial diversity of the agricultural landscape, some have advanced the notion that many policies aimed at addressing the multifunctional nature of agriculture must be administered at sub-national, regional, or local levels (Blandford and Boisvert, forthcoming; Gundersen et al., 2001). Other issues that have trans-boundary implications will require involvement at the national and international level. Regardless of the level of government administration, such a policy paradigm would separate agricultural trade policy from policies designed to move us closer to optimal levels of socially valued non-commodity outputs. 


\section{Footnotes}

${ }^{1}$ This characterization of multifunctionality in terms of joint production is developed more fully by Boisvert (2001a,b) in two annexes of an OECD report on the subject. He identifies three general causes of jointness: (a) technical interdependencies in production processes, such as honey bees that pollinate fruit trees, (b) non-allocable inputs, where inputs are devoted to a process that produces more than one output and the input's separate contribution to each output cannot be determined, and (c) allocable fixed factors, where outputs are produced in separate processes and inputs can be allocated across the processes, but they compete for inputs that are fixed at the firm level (e.g., producing several crops on a fixed land base).

${ }^{2}$ Some high-cost countries have asserted that subsidising the private output is socially efficient, because it makes up for the difference between the public and private values of the bundle of farm outputs. As we formally demonstrate below, this assertion is invalid in general because it implicitly assumes that all outputs are produced in fixed proportions. Even in the fixed proportions case, a subsidy for the public benefits of one commodity would only be efficient if the public values of all competing commodities are also internalised.

${ }^{3}$ For their part, some of the low-cost countries have argued that an efficient policy would have a negligible effect on the production of private outputs. This argument does not hold in general if the private and public outputs are jointly produced, because altering the prices of the public goods from zero to their social values may change the supply of the private output.

${ }^{4}$ If the industry in question is a large user of one of the inputs, then the factor prices will be endogenous movements along a factor supply curve. This type of interaction is addressed in the empirical section below.

${ }^{5}$ Since tariffs are bound by agreed upon formulas in the WTO rules, we assume they are fixed. 
${ }^{6}$ To verify, the implicit function $p_{y}(L, Z)$ is defined by: $F(L, Z)=x\left(p_{y}(L, Z)\right)+x^{*}\left(p_{y}(L, Z)\right)$. Differentiating this expression with respect to $\mathrm{L}$ and $\mathrm{Z}_{\mathrm{i}}$ and rearranging, $\partial \mathrm{p}_{\mathrm{y}} / \partial \mathrm{L}=\mathrm{F}_{\mathrm{L}}() /.\left[\mathrm{x}^{\prime}\left(\mathrm{p}_{\mathrm{y}}\right)+\right.$ $\left.\mathrm{x}^{* \prime}\left(\mathrm{p}_{\mathrm{y}}\right)\right]$ and $\partial \mathrm{p}_{\mathrm{y}} / \partial \mathrm{Z}_{\mathrm{i}}=\mathrm{F}_{\mathrm{z}_{\mathrm{i}}}(\cdot) /\left[\mathrm{x}^{\prime}\left(\mathrm{p}_{\mathrm{y}}\right)+\mathrm{x}^{* \prime}\left(\mathrm{p}_{\mathrm{y}}\right)\right]$. Both these expressions are negative since their numerators are positive and their denominators are negative.

${ }^{7}$ The last expression is negative because it has the same sign as $g(z) / z-g^{\prime}(z)$, which must be less than zero by the Mean Value Theorem. Intuitively this follows because "average pollution" $\mathrm{g}(\mathrm{z}) / \mathrm{z}$ must be less than "marginal pollution" $\mathrm{g}^{\prime}(\mathrm{z})$ if $\mathrm{g}$ is convex (the opposite of the analogous relationships for a concave production function). If land is heterogeneous, the effect of bringing an extra acre into production depends on the environmental vulnerability of the acre in question. ${ }^{8}$ The public goods will not be supplied in efficient quantities even if the demands for a and e are independent and have been estimated correctly. If there are significant cross-effects in consumption, then care must be taken in jointly estimating the non-market values (Randall, 1991).

${ }^{9}$ In particular, it is assumed that $\mathrm{L}$ and $\mathrm{Z}$ may be substituted for each other, but the inputs within each input aggregate are combined in fixed proportions. This implies that the price of each input aggregate is a linear expression of the prices within it. Peterson et al. (1999) establish that these assumptions lead to a lower bound estimate on the subsidy and an upper bound estimate on the tax.

${ }^{10}$ Recall that a marginal change in farmland decreases pollution because it reduces input intensity $\mathrm{z}=\mathrm{Z} / \mathrm{L}$ when $\mathrm{Z}$ is fixed and $\mathrm{g}(\mathrm{z})$ is convex. This does not imply that acreage reduction policies such as the Conservation Reserve Program in the U.S. will increase pollution, since the total use of non-land inputs $(\mathrm{Z})$ would change with the number of acres in production. 
${ }^{11}$ This behaviour is often formalised in political economy models where governments are assumed to maximise some combination of the social welfare function and a political support function (de Gorter, 2002).

${ }^{12}$ In our discussion, we have not formally addressed the effects of multifunctionality policies on developing countries. Some high-cost countries have argued that lower farm subsidies and freer trade would degrade the environment in the developing world, because additional production would be generated in countries with limited environmental regulations. The developing countries have countered that protected agriculture in rich countries leads to unfair competition in world markets and perpetuates the poverty problem. The weight of current empirical evidence suggests that freer trade would improve environmental quality in all countries (e.g., Anderson, 1992), but the effects on the levels of other important multifunctional outputs in developing countries is not well understood, and is clearly an important topic for future research. 


\section{References}

Ahearn, M., Yee, J., Ball, V.E., Nehring, R., Somwaru, A. and Evans, R. (1998). Agricultural Productivity in the United States. No. 740, United States Department of Agricultural, Economic Research Service. Washington DC. Bulletin.

Anderson, K. (1992). Agricultural Trade Liberalization and the Environment: A Global Perspective. The World Economy 15: 153-72.

Anderson, K. and Hoekman, B. (1999). Agriculture and the New Trade Agenda. American Economic Association Annual Meeting, New York.

Ball, V.E., Bureau, J., Nehring, R. and Somwaru, A. (1997). Agricultural Productivity Revisited. American Journal of Agricultural Economics 79: 1045-1063.

Baumol, W.J., Panzar, J. and Willig, R. (1981). Contestable Markets and the Theory of Market Structure. New York: Harcourt, Brace, and Jovanovich.

Beasley, S.D., Workman, W.C. and Williams, N.A. (1986). Estimating Amenity Values on Urban Fringe Farmland: A Contingent Valuation Approach. Growth and Change 17: 7078.

Beghin, J., Dessus, S., Roland-Holst, D. and van der Mensbrugghe, D. (1997). The Trade and Environment Nexus in Mexican Agriculture: A General Equilibrium Analysis. Agricultural Economics 17: 115-132.

Bergstrom, J.C., Sillman, B.L. and Stoll, J.R. (1985). Public Environmental Amenity Benefits of Private Land: The Case of Prime Agricultural Land. Southern Journal of Agricultural Economics 17: 139-149.

Bhagwati, J.N. (1969). Trade, Tariffs and Growth. Cambridge, Massachusetts: MIT Press.

Blandford, D. and Boisvert, R.N. (forthcoming). Multifunctional Agriculture and Domestic/International Policy Choice. Estey Centre Journal of International Law and Trade Policy.

Blandford, D. and Fulponi, L. (1999). Emerging Public Concerns in Agriculture: Domestic Policies and International Trade Commitments. European Review of Agricultural Economics 26: 409-424.

Bohman, M., Cooper, J., Mullarkey, D., Normile, M.A., Skully, D., Vogel, S. and Young, E. (1999). The Use and Abuse of Multifunctionality. Economic Research Service, USDA November.

Boisvert, R. (2001a). A Note on the Concept of Jointness in Production. Annex 1, in Multifunctionality: Toward an Analytical Framework. Paris: OECD. 
Boisvert, R. (2001b). Joint Production in Four Outputs: Two Commodities and Positive and Negative Externalities. Annex 2, in Multifunctionality: Toward an Analytical Framework. Paris: OECD.

Carlson, S. (1956). A Study of the Pure Theory of Production. New York: Kelley and Millman.

Copeland, B.R. (1994). International Trade and the Environment: Policy Reform in a Polluted Small Open Economy. Journal of Environmental Economics and Management 26: 44-65.

de Gorter, H. (2002). "Political Economy of Agricultural Policy" in Handbook of Agricltural Economics, B. Garnder and G. Rausser (eds), Elsevier-North Holland Publishing Co., Amsterdam, the Netherlands, forthcoming.

Environmental Working Group. (1996). Pouring it On: Nitrate Contamination of Drinking Water. Washington, DC. Unpublished manuscript.

Floyd, J.E. (1965). The Effects of Farm Price Supports on the Return to Land and Labor in Agriculture. The Journal of Political Economy 73: 148-158.

Gardner, B.L. (1987). The Economics of Agricultural Policies. Macmillan. New York.

Gundersen, C., Kuhn, B., Offutt, S. and Morehart, M. (2001). A Consideration for the Devolution of Federal Agricultural Policy. Unpublished Paper.

Halstead, J.M. (1984). Measuring the Nonmarket Value of Massachusetts Agricultural Land: A Case Study. Journal of the Northeastern Agricultural Economics Council 13: 12-19.

Holtermann, S. (1976). Alternative Tax Systems to Correct for Externalities, and the Efficiency of Paying Compensation. Economica 43: 1-16.

Krutilla, K. (1991). Environmental Regulation in an Open Economy. Journal of Environmental Economics and Management 20: 127-42.

Lau, L. (1972). Profit Functions of Technologies with Multiple Inputs and Outputs. Review of Economics and Statistics 54: 281-289.

Leathers, H. (1991). Allocable Fixed Inputs as a Cause of Joint Production: A Cost Function Approach. American Journal of Agricultural Economics 73: 1083-1090.

Lindland, J. (1998). Non-Trade Concerns in a Multifunctional Agriculture. OECD Workshop on Emering Trade Issues in Agriculture. Paris.

Marshall, A. (1959). Principles of Economics. Eighth Edition. New York: MacMillan. 
Norwegian Royal Ministry of Agriculture. (1998). Non-Trade Concerns in a Multifunctional Agriculture: Implications for Agricultural Policy and the Multilateral Trading System.

Organization for Economic Cooperation and Development. (1997). Environmental Benefits from Agriculture: Issues and Policies. OECD. Paris.

Peterson, J.M. (2000). Essays on Environmental Policy Design for Agricultural Under Multifunctionality, Spatial Variability, and Risk. Unpublished Ph.D. Dissertation, Department of Agricultural, Resource, and Managerial Economics, Cornell University: Ithaca, New York.

Peterson, J.M., Boisvert, R.N. and de Gorter, H. (1999). Multifunctionality and Optimal Environmental Policies for Agriculture in an Open Economy. Department of Agricultural, Resource, and Managerial Economics, Cornell University. Ithaca, NY. Working Paper 99-29.

Pimentel, D., Acquay, H., Biltonen, P., Rice, P., Silva, M., Nelson, J., Lipner, J., Giordano, S., Horowitz, A. and D'Amore, D. (1992). Environmental and Economic Costs of Pesticide Use. BioScience 42: 750-60.

Poe, G.L. (1998). Valuation of Groundwater Quality Using a Contingent Valuation Damage Function Approach. Water Resources Research 34: 3627-33.

Poe, G.L. (1999). Maximizing the Environmental Benefits per Dollar Expanded': An Economic Interpretation and Review of Agricultural Environmental Benefits and Costs. Society and Natural Resources 12: 571-98.

Powell, J.R. (1990). The Value of Groundwater Protection: Measurement of Willingness-to-Pay Information and its Utilization by Local Government Decision-Makers. Unpublished Ph.D. Dissertation, Department of Agricultural Economics, Cornell University: Ithaca, NY.

Randall, A. (1991). Total and Nonuse Values. In J. B. Braden and C. D. Kolstad (eds.), Measuring the Demand for Environmental Quality. Amsterdam: North Holland Publishers.

Runge, C.F. (1998). Emerging Issues in Agricultural Trade and the Environment. OECD Workshop on Emerging Trades in Agriculture. Paris.

Schamel, G. and de Gorter, H. (1997). Trade and the Environment: Domestic versus Global Perspectives. Humboldt University. Berlin, Germany. Unpublished manuscript.

Schultz, S.D. and Lindsay, B.E. (1990). The Willingness to Pay for Groundwater Protection. Water Resources Research 26: 1869-75. 
Shumway, C., Pope, R. and Nash, E. (1984). Allocable Fixed Inputs and Jointness in Agricultural Production. American Journal of Agricultural Economics 66: 72-78.

Spulber, D.F. (1985). Effluent Regulation and Long-run Optimality. Journal of Environmental Economics and Management 12: 103-116.

Stevens, B.K. (1988). Fiscal Implications of Effluent Charges and Input Taxes. Journal of Environmental Economics and Management 15: 285-296.

Vatn, A. (forthcoming). Multifunctional Agriculture - Some Consequences for International Trade Regimes. European Review of Agricultural Economics.

World Trade Organization. (1998). Non Trade Concerns in the Next Agricultural Negotiations. Submission by Argentina to the Committee on Trade and Environment. WT/CTE/W/97, Geneva, Switzerland.

World Trade Organization. (1999). Preparations for the 1999 Ministerial Conference: Negotiates on Agriculture. Communication from Japan to the General Council. WT/GC/W/220, Geneva, Switzerland. 
Table 1. Parameter Values

\begin{tabular}{lccc}
\hline Parameter & Symbol & Base Value & Range \\
\hline Elasticity of domestic demand & $\eta_{\mathrm{x}}$ & 0.3 & $0.2-0.5$ \\
Elasticity of export demand & $\eta_{\mathrm{x}}{ }^{*}$ & 5 & $2-10$ \\
Supply elasticity of L & $\eta_{\mathrm{L}}$ & 0.2 & $0.1-0.3$ \\
Supply elasticity of Z & $\eta_{\mathrm{Z}}$ & 10 & $5-15$ \\
Production elasticity of L & $\beta_{\mathrm{L}}$ & 0.71 & $0.5-0.9$ \\
Production elasticity of Z & $\beta_{\mathrm{Z}}$ & 0.29 & $0.1-0.5$ \\
Marginal value of amenities (\$/a) & $\gamma$ & 5 & $0-10$ \\
Aggregate external health costs (\$billion) & $\mathrm{e}$ & 3.5 & $2-5$ \\
\end{tabular}


Table 2. Base Data and Simulation Results ${ }^{a}$

\begin{tabular}{|c|c|c|c|c|c|}
\hline \multirow[b]{2}{*}{ Variable } & \multirow[b]{2}{*}{$\begin{array}{l}\text { Base Data } \\
\text { (1994) }\end{array}$} & \multicolumn{3}{|c|}{ No Trade Distortion } & \multirow[b]{2}{*}{$\begin{array}{c}\text { Optimal } \\
\text { Domestic } \\
\text { Policy }\end{array}$} \\
\hline & & $\begin{array}{l}\text { Tax Only } \\
\text { (Scenario 1) }\end{array}$ & $\begin{array}{l}\text { Subs. Only } \\
\text { (Scenario 2) }\end{array}$ & $\begin{array}{c}\text { Optimal } \\
\text { Policy } \\
\text { (Scenario 3) }\end{array}$ & \\
\hline Land Subsidy (\$/acre) & 0.00 & 0.00 & 5.00 & 7.84 & -7.38 \\
\hline Chemical Tax (\$/lb.) & 0.00 & 0.140 & 0.00 & 0.139 & 0.29 \\
\hline Food Price $^{b}$ & 1.00 & $\begin{array}{l}1.04 \\
3.79\end{array}$ & $\begin{array}{c}0.99 \\
-0.53\end{array}$ & $\begin{array}{l}1.03 \\
2.85\end{array}$ & $\begin{array}{l}1.09 \\
8.70\end{array}$ \\
\hline Production ( $\$$ billion) & 166.61 & $\begin{array}{l}161.73 \\
-2.93\end{array}$ & $\begin{array}{c}167.36 \\
0.45\end{array}$ & $\begin{array}{l}162.86 \\
-2.25\end{array}$ & $\begin{array}{l}156.43 \\
-6.11\end{array}$ \\
\hline Net Exports ( $\$$ billion) & 19.17 & $\begin{array}{c}15.92 \\
-16.96\end{array}$ & $\begin{array}{c}19.69 \\
2.69\end{array}$ & $\begin{array}{c}16.66 \\
-13.11\end{array}$ & $\begin{array}{c}12.63 \\
-34.11\end{array}$ \\
\hline Consumption ( $\$$ billion) & 147.44 & $\begin{array}{c}145.81 \\
-1.11\end{array}$ & $\begin{array}{c}147.68 \\
0.16\end{array}$ & $\begin{array}{c}146.21 \\
-0.84\end{array}$ & $\begin{array}{l}143.80 \\
-2.47\end{array}$ \\
\hline $\begin{array}{l}\text { Agricultural Land } \\
\text { (million acres) }\end{array}$ & 975 & $\begin{array}{l}976 \\
0.12\end{array}$ & $\begin{array}{l}981 \\
0.67\end{array}$ & $\begin{array}{l}986 \\
1.14\end{array}$ & $\begin{array}{c}968 \\
-0.68\end{array}$ \\
\hline Rent on Land (\$/acre) & 121.3 & $\begin{array}{c}122.10 \\
0.62\end{array}$ & $\begin{array}{c}125.45 \\
3.38\end{array}$ & $\begin{array}{c}128.46 \\
5.86\end{array}$ & $\begin{array}{l}117.31 \\
-3.33\end{array}$ \\
\hline $\begin{array}{l}\text { Chemical Use } \\
\text { (billion lb.) }\end{array}$ & 44.8 & $\begin{array}{c}40.3 \\
-10.03\end{array}$ & $\begin{array}{c}44.8 \\
-0.07\end{array}$ & $\begin{array}{c}40.3 \\
-10.09\end{array}$ & $\begin{array}{c}36.6 \\
-18.20\end{array}$ \\
\hline $\begin{array}{l}\text { Price of Chemicals } \\
\text { (\$/lb.) }\end{array}$ & 1.08 & $\begin{array}{c}1.07 \\
-1.05\end{array}$ & $\begin{array}{c}1.08 \\
-0.01\end{array}$ & $\begin{array}{c}1.07 \\
-1.06\end{array}$ & $\begin{array}{c}1.06 \\
-1.99\end{array}$ \\
\hline $\begin{array}{l}\text { Input Intensity } \\
\text { (lb./acre) }\end{array}$ & 45.96 & $\begin{array}{c}41.30 \\
-10.14\end{array}$ & $\begin{array}{l}45.62 \\
-0.74\end{array}$ & $\begin{array}{c}40.85 \\
-11.11\end{array}$ & $\begin{array}{c}37.85 \\
-17.65\end{array}$ \\
\hline Health Costs ( $\$$ billion) & 3.50 & $\begin{array}{c}2.83 \\
-19.15\end{array}$ & $\begin{array}{c}3.47 \\
-0.81\end{array}$ & $\begin{array}{c}2.80 \\
-20.08\end{array}$ & $\begin{array}{c}2.36 \\
-32.64\end{array}$ \\
\hline $\begin{array}{l}\text { Land Amenity Value } \\
\text { (\$ billion) }\end{array}$ & 4.87 & $\begin{array}{l}4.88 \\
0.12\end{array}$ & $\begin{array}{l}4.91 \\
0.67\end{array}$ & $\begin{array}{l}4.93 \\
1.14\end{array}$ & $\begin{array}{c}4.84 \\
-0.68\end{array}$ \\
\hline $\begin{array}{l}\text { Change in Dom. Welfare } \\
\text { (\$ billion) }\end{array}$ & --- & 1.04 & -0.06 & 0.92 & 1.36 \\
\hline $\begin{array}{l}\text { Change in For. Welfare } \\
\text { (\$billion) }\end{array}$ & --- & -0.66 & 0.10 & -0.51 & -1.36 \\
\hline
\end{tabular}

\footnotetext{
${ }^{a}$ Numbers in italics are percentage changes from base values.

${ }^{b}$ Index of all agricultural prices, $1994=1$.
} 
Table 3. Optimal Taxes, Subsidies, and Prices at Different Parameter Values

\begin{tabular}{|c|c|c|c|c|c|c|}
\hline \multirow[b]{3}{*}{ Parameter Values } & \multicolumn{3}{|c|}{ No Trade Distortion } & \multicolumn{3}{|c|}{ Optimal Domestic Policy } \\
\hline & Land & Chemical & Food & Land & Chemical & Food \\
\hline & Subsidy & Tax & Price & Subsidy & Tax & Price \\
\hline \multicolumn{7}{|l|}{ Base Values } \\
\hline \multicolumn{7}{|c|}{ Elasticity of Domestic Demand } \\
\hline $\operatorname{Low}\left(\eta_{x}=0.2\right)$ & 7.85 & 0.14 & 1.03 & -9.51 & 0.31 & 1.10 \\
\hline $\operatorname{High}\left(\eta_{\mathrm{x}}=0.5\right)$ & 7.82 & 0.14 & 1.03 & -4.63 & 0.26 & 1.07 \\
\hline \multicolumn{7}{|l|}{ Elasticity of Export Demand } \\
\hline $\operatorname{Low}\left(\eta_{\mathrm{x}}{ }^{*}=2\right)$ & 7.89 & 0.14 & 1.04 & -19.27 & 0.42 & 1.17 \\
\hline $\operatorname{High}\left(\eta_{\mathrm{x}}^{*}=10\right)$ & 7.79 & 0.14 & 1.02 & -1.36 & 0.22 & 1.05 \\
\hline \multicolumn{7}{|l|}{ Supply Elasticity of L } \\
\hline $\operatorname{Low}\left(\eta_{\mathrm{L}}=0.1\right)$ & 7.87 & 0.14 & 1.03 & -7.42 & 0.29 & 1.08 \\
\hline $\operatorname{High}\left(\eta_{L}=0.3\right)$ & 7.81 & 0.14 & 1.02 & -7.35 & 0.29 & 1.09 \\
\hline \multicolumn{7}{|l|}{ Supply Elasticity of Z } \\
\hline Low $\left(\eta_{\mathrm{z}}=5\right)$ & 7.88 & 0.14 & 1.03 & -7.44 & 0.29 & 1.08 \\
\hline $\operatorname{High}\left(\eta_{z}=15\right)$ & 7.82 & 0.14 & 1.03 & -7.36 & 0.29 & 1.09 \\
\hline \multicolumn{7}{|l|}{ Production Elasticity of L } \\
\hline $\operatorname{Low}\left(\beta_{\mathrm{L}}=0.5, \beta_{\mathrm{Z}}=0.5\right)$ & 8.06 & 0.14 & 1.03 & -2.40 & 0.39 & 1.11 \\
\hline $\operatorname{High}\left(\beta_{\mathrm{L}}=0.9, \beta_{\mathrm{Z}}=0.1\right)$ & 7.12 & 0.12 & 1.02 & -12.79 & 0.18 & 1.06 \\
\hline \multicolumn{7}{|l|}{ Marginal Value of Amenities } \\
\hline $\operatorname{Low}(\gamma=0)$ & 2.88 & 0.14 & 1.03 & -12.29 & 0.29 & 1.09 \\
\hline $\operatorname{High}(\gamma=10)$ & 12.80 & 0.14 & 1.02 & -2.46 & 0.29 & 1.08 \\
\hline \multicolumn{7}{|l|}{ Health Costs } \\
\hline Low $(\mathrm{e}=2)$ & 6.77 & 0.08 & 1.01 & -8.64 & 0.23 & 1.07 \\
\hline $\operatorname{High}(\gamma=5)$ & 8.76 & 0.19 & 1.04 & -6.27 & 0.34 & 1.10 \\
\hline
\end{tabular}

